\title{
Game Edukasi Berbasis Kinect untuk Anak Berkebutuhan Khusus (Autis) dengan Metode Finite State Machine
}

\author{
Dhimas Mulia Anugraha ${ }^{1}$, Ina Agustina ${ }^{2}$ Fauziah $^{3}$ \\ Idhimas12ia1@gmail.com, ${ }^{2}$ ina.agustina@civitas.unas.ac.id, ${ }^{3}$ fauziah@civitas.unas.ac.id
}

Program Studi Teknik Informatika Fakultas Teknologi Komunikasi dan Informatika, Universitas Nasional

\begin{abstract}
Game is a development in technology today. Educational game is a game designed to be a medium of learning through material that contains text, video, audio, images animation.Game is intended for children with special needs. Children with special needs are children who have special characters compared with children in general. One of the children with special needs is a child with autism. In the completion of the game process using finite state machine method.Method finite state machine function to determine the flow of users in answering a question that appears in the game. The purpose of this study is to implement educational games based on kinect for children with special needs autism familiar objects in the house and implements finite state machine method to help users know the game plot when played. From the research results can be concluded the average ideal distance kinect and users in playing the game is 2.2 meters. User response time in selecting button in the game is 1.4 seconds. The average of best and worst FPS is 113.2 fps and 82.5 fps.
\end{abstract}

Abstrak-- Game merupakan perkembangan dalam teknologi saat ini. Game edukasi merupakan permainan yang dirancang untuk dijadikan sebuah media pembelajaran melalui materi yang berisikan teks,video,audio,gambar dan animasi. Game ini ditujukan untuk anak berkebutuhan khusus. Anak berkebutuhan khusus merupakan anak yang mempunyai karakter khusus dibandingkan dengan anak pada umumnya. Salah satu dari anak berkebutuhan khusus adalah anak autis. Autis merupakan gangguan saraf seseorang. Dalam penyelesaian proses game menggunakan metode finite state machine. Metode finite state machine berfungsi untuk menentukan alur pengguna dalam menjawab suatu pertanyaan yang tampil dalam game. Tujuan dalam penelitian ini adalah mengimplementasikan game edukasi berbasis kinect untuk anak berkebutuhan khusus autis mengenal benda di dalam rumah serta mengimplementasikan metode finite state machine untuk membantu pengguna mengetahui alur game saat dimainkan. Dari hasil penelitian dapat disimpulkan rata-rata jarak ideal kinect dan pengguna dalam memainkan game adalah 2,2 meter. Waktu respon pengguna dalam memilih tombol button dalam game adal ah 1,4 detik. Rata-rata FPS terbaik dan terburuk adalah 113,2 fps dan 82,5 fps.

Kata kunci - Autis, Finite State Machine,Game, Kinect

\section{PENDAHULUAN}

Game merupakan perkembangan dalam teknologi saat ini. Game banyak dimainkan sebagai media hiburan.Seiring dengan perkembangan game,game tidak hanya dijadikan sebuah media hiburan tetapi juga meningkatkan kemampuan berpikir seseorang. Game edukasi merupakan permainan yang dirancang untuk dijadikan sebuah media pembelajaran melalui materi yang berisikan teks,video,audio,gambar dan animasi [1][3].

Game edukasi [8][9] bertujuan untuk memberikan pemahaman yang lebih dalam materi. Dalam game edukasi pengguna dapat bermain sambil belajar. Game in i ditujukan untuk anak berkebutuhan khusus. Anak berkebutuhan khusus merupakan anak yang mempunyai karakter khusus dibandingkan dengan anak pada umumnya. Salah satu dari anak berkebutuhan khusus adalah anak autis. Autis merupakan gangguan saraf seseorang. Penderita autis mengalami kesulitan dalam berkomunikasi maupun bersosialisasi dengan orang lain. Dengan memanfaatkan perangkat laptop dan kinect sebagai inputan pengguna lebih interaktif untuk memainkan game. Dalam penyelesaian proses game menggunakan metode finite state machine [10][11].

Metode finite state machine berfungsi untuk menentukan alur pengguna dalam menjawab suatu pertanyaan yang tampil dalam game. Penulis membuat suatu game edukasi berbasis kinect yang digunakan dalam mengenal benda didalam ru mah dengan metode finite state machine, sehingga dapat membantu anak berkebutuhan khusus(autis) untuk mengenal benda di dalam rumah dengan sistem inputan menggunakan kinect [12] [13].

Hasil penelitian sebelumnya menerapkan finite state machine untuk proses alur kontrol permainan game dimana player akan melengkapi jawaban setiap level untuk dapat melanjutkan ke level berikutnya [1].

Dalam penelitian ini dirancang sebuah game edukasi berbasis kinect untuk anak berkebutuhan khusus autis untuk mengenal benda di dalam rumah dengan mengimplementasikan metode finite state machine untuk membantu pengguna mengetahui alur game saat dimain kan, mengetahui proses dalam game, mengetahui jarak ideal antara kinect dan pengguna,meminimalisir loading yang terjadi saat game dimainkan dan pemanfaatan laptop dalam implementasi game.

\section{KAJIAN PUSTAKA}

Finite State Machine merupakan implementasi dari bahasa automata. Finite State Machine merupakan mesin abstrak yang mampu menerima maupun menolak inputan. Finite State Machine (FSM) adalah sebuah metodologi 
perancangan sistem kontrol yang menggabarkan tingkah laku atau prinsip kerja sistem dengan menggunakan tiga hal sebagai berikut: state (keadaan), events (kejadian) dan action (aksi) [6].

Pada penelitian sebelumnya finite state machine digunakan untuk menggambarkan perilaku pada game yang me mpunyai tahap pengerjaan, tahap pertama mendefinisikan perilaku yang ada, menggambarkan perilaku pada state,berikutnya adalah menentukan transisi antar state dan kondisi, terakhir adalah menggabungkan semua state dan transisi[2].

Finite state machine digunakan untuk mendukung interaksi yang terdiri dari serangkaian state yang menentukan keputusan dan setiap state dapat berpindah ke state lainnya, jika memenuhi kondisi yang telah ditentukan sebelumnya[3][4]. Finite state machine digunakan untuk mendeteksi adanya pola kesalahan pada waktu pengerjaan soal penjumlahan susun dan untuk menyimpan informasi dari setiap tahap mengerjakan soal[4]. Finite state machine digunakan untuk membangun sistem reward imersif $\mathrm{di}$ dalam lingkungan game. Pemain akan bermain game dengan memilih kondisi-kondisi tertentu yang ada dalam lingkungan game dan dalam kondisi-kondisi yang dipilih akan mengakibatkan perpindahan state [5].

\section{Finite State Machine}

\section{METODE PENELITIAN}

Dalam Finite State Machine (FSM) sistem kontrol yang menggabarkan tingkah laku atau prinsip kerja sistem dengan menggunakan tiga hal sebagai yang antara lain adalah: state (keadaan), events (kejadian) dan action (aksi) [6].

Dalam game ini terdapat 3 state yang dituangkan dalam pilihan level. Level mudah, sedang dan sulit. Misalnya pengguna memilih level mudah maka akan masuk dalam tampilan game memilih obyek. Dalam game terdapat timer untuk membatasi pengguna untuk menjawab soal yang ditanyakan jika timer habis dan pengguna belum menjawab pertanyaan maka akan kembali ke pertanyaan sebelumnya.

\section{Perancangan Sistem}

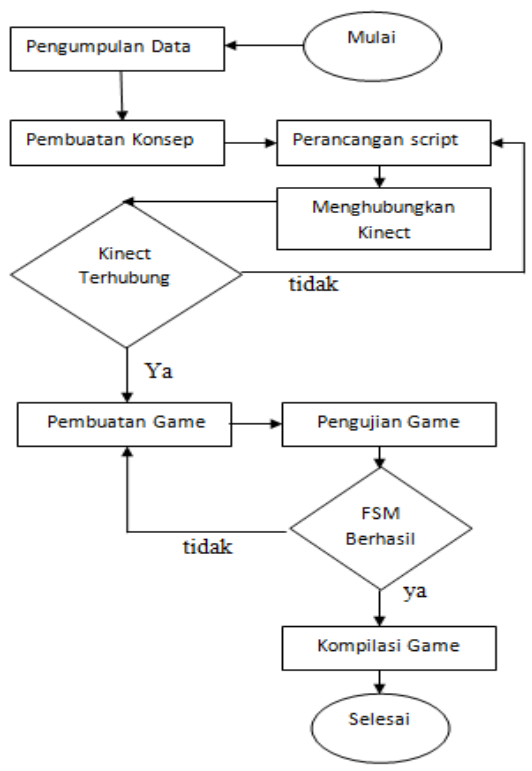

Gambar 1. Flowchart Perancangan Sistem

Perancangan sistem dimulai dengan proses pengumpulan data.Setelah data terkumpul, selanjutnya pembuatan konsep game yang akan dibuat. Setelah konsep dibuat perancangan script di Unity 3D dapat dilakukan.

Selanjutnya menghubungkan kinect dengan Unity 3D yang sudah dibuat. Jika kinect belum terhubung akan kembali ke perancangan script dan jika kinect sudah terhubung maka dilanjutkan dengan pembuatan game. Setelah game jadi maka akan dilakukan pengujian. Dalam pengujian akan memastikan proses finite state machine berhasil dan dapat digunakan dengan baik. Jika finite state machine belum berhasil maka akan kembali dalam pembuatan game.

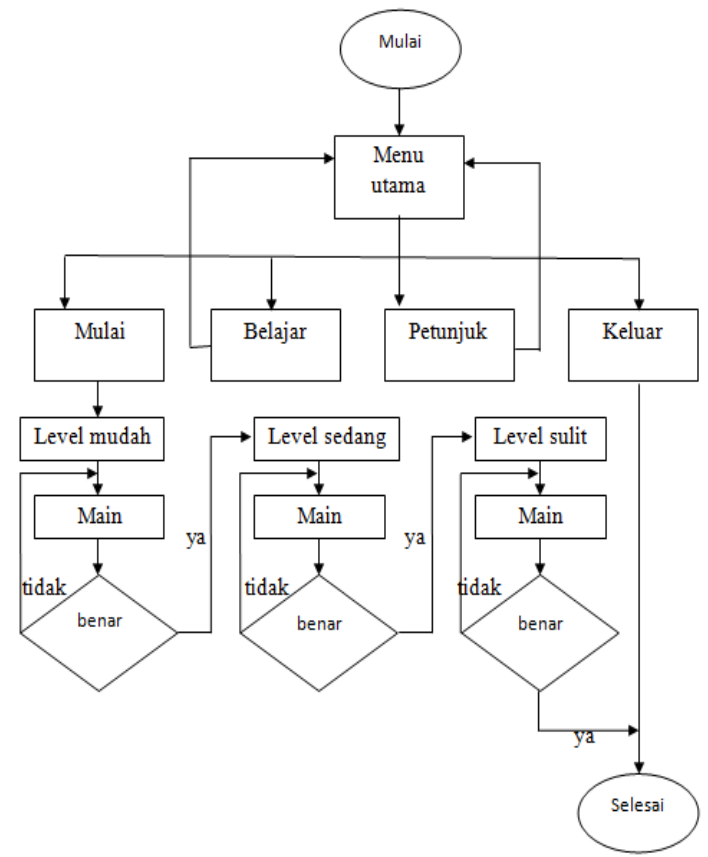

Gambar 2. Flowchart Perancangan Game

Game terdiri dari level mudah, sedang dan sulit dengan soal memilih objek,melengkapi kata dan berhitung. Game dimulai dengan memilih level yang tersedia di tampilan pilih level. Jika pengguna dapat menjawab setiap soal pada level dengan benar, maka pengguna akan masuk ke level selanjutnya. Jika pengguna tidak dapat menja wab soal maka akan kembali ke pertanyaan sebelumnya.

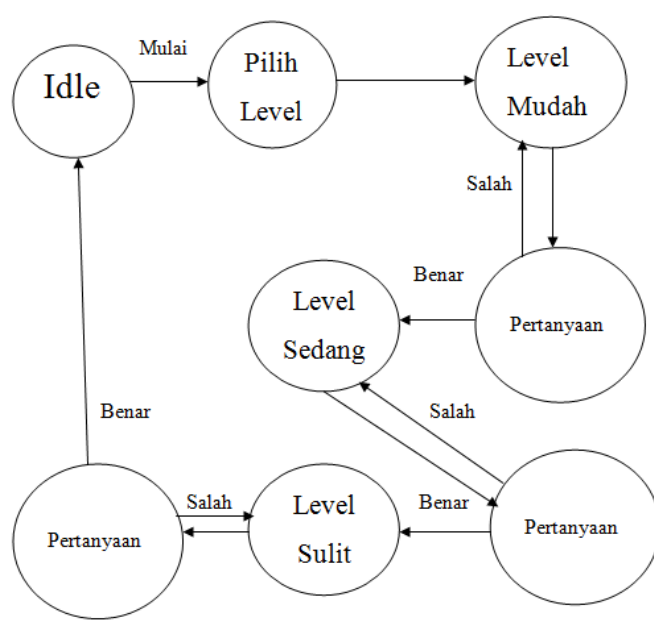

Gambar 3.Desain FSM Gameplay

\section{HASIL DAN PEMBAHASAN}

Perangkat kinect sebagai input dan manangkap atau merekam gerakan tangan kanan saja yang digunakan sebagai kursor dalam memainkan game. Implementasi game pada 
anak autis dengan kriteria dapat membaca teks dan mempunyai daya ingat yang cukup.

\section{A. Analisis Kebutuhan}

Implementasi game pada laptop dengan ram $4 \mathrm{~Gb}$ dan kecepatan processor lebih dari $2 \mathrm{Ghz}$. Dalam alur permainan menggunakan metode finite state machine. Dalam penelitian ini menggunakan beberapa perangkat keras dan lunak yaitu sebagaiberikut:

Tabel 1

Spesifikasi Perangkat keras

\begin{tabular}{|c|c|}
\hline Perangkat & Spesifikasi \\
\hline Processor & Intel (R) Celeron (R) \\
\hline VGA & Intel (R) HD Graphics \\
\hline Harddisk & 500 GB \\
\hline RAM & 4 GB \\
\hline Kinect XBOX 360 & Versi 1.8 \\
\hline
\end{tabular}

Tabel 2

Kebutuhan perangkat lunak

\begin{tabular}{|c|}
\hline Perangkat \\
\hline Unity 3D 5.4.2 32-Bit \\
\hline Blender 2.77a \\
\hline Adobe Photoshop CS6 (64bit) \\
\hline Adobe Audition CS6 \\
\hline Developer Toolkit Browser \\
v1.8.0 \\
\hline Kinect Studio v1.8 \\
\hline
\end{tabular}

\section{B. Storyboard Game}

1. Materi game:memilih objek,melengkapi kata,dan berhitung

2. Deskripsi game:game in i termasuk game pendidikan atau edukasi dengan tema mengenal benda di dalam rumah.

3. Game tediri dari 3 level,setiap level memiliki pertanyaan yang berbeda-beda. Untuk level mudah terdiri dari 2 pertanyaan, level sedang 3 pertanyaan dan level sulit 4 pertanyaan.

\section{Proses FSM (Finite State Machine)}

Untuk proses Finite State Machine terdapat diagram rancangan game dengan FSM.

Inisialisasi input : Salah : $0 \rightarrow$ Kembali

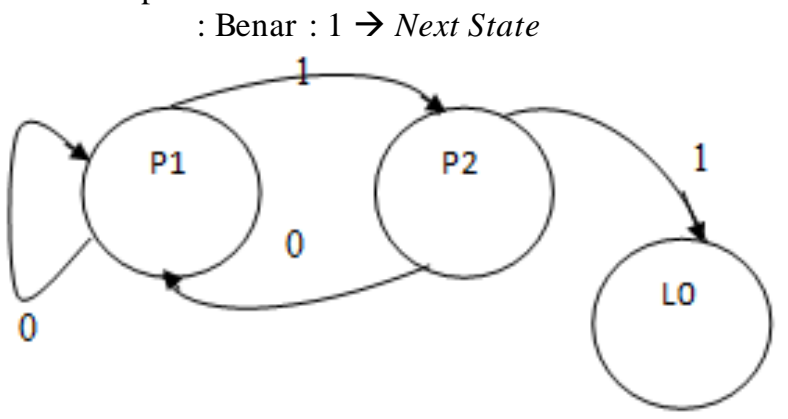

Gambar 4. Diagram FSM Level Mudah

Dari diagram FSM diatas dapat dituliskan ke dalam tabel transisi sebagaiberikut:

Tabel 3.

Transisi FSM Level Mudah

\begin{tabular}{|c|c|c|}
\hline State & 0 & 1 \\
\hline $\mathrm{P} 1$ & $\mathrm{P} 1$ & $\mathrm{P} 2$ \\
\hline $\mathrm{P} 2$ & $\mathrm{P} 1$ & $\mathrm{~L} 0$ \\
\hline $\mathrm{L} 0$ & $\varnothing$ & $\varnothing$ \\
\hline
\end{tabular}

Pada Tabel 3 tersebut P1 merupakan pertanyaan 1: Jika pertanyaan 1 dijawab dengan benar, maka next state ke pertanyaan 2. Jika pertanyaan 1 di jawab salah maka akan kembali ke pertanyaan 1. P2 merupakan pertanyaan 2: Jika pertanyaan 2 dija wab dengan benar, maka next state game ke level sedang. Jika pertanyaan 1 di jawab salah maka akan kembali ke pertanyaan 1 . L0 merupakan level sedang tidak ada transisi state level sedng di level mudah.

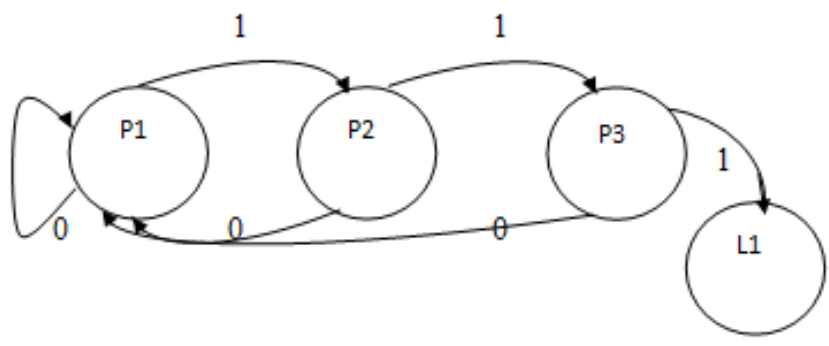

Gambar 5.Diagram FSM Level Sedang

Tabel 4

Transisi FSM Level Sedang

\begin{tabular}{|c|c|c|}
\hline State & 0 & 1 \\
\hline P1 & P1 & P2 \\
\hline P2 & P1 & P3 \\
\hline P3 & P1 & L1 \\
\hline L1 & $\varnothing$ & $\varnothing$ \\
\hline
\end{tabular}

P1 merupakan pertanyaan 1: Jika pertanyaan 1 dijawab dengan benar, maka next state ke pertanyaan 2. Jika pertanyaan 1 di jawab salah maka akan kembali ke pertanyaan 1. P2 merupakan pertanyaan 2: Jika pertanyaan 2 dija wab dengan benar, maka next state ke pertanyaan 3. Jika pertanyaan 2 di jawab salah maka akan kembali ke pertanyaan 1. P3 merupakan pertanyaan 3: Jika pertanyaan 3 dijawab dengan benar, maka next state game ke level sulit. Jika pertanyaan 3 di jawab salah maka akan kembali ke pertanyaan 1. L1 merupakan level sulit tidak ada transisi state level sulit di level sedang.

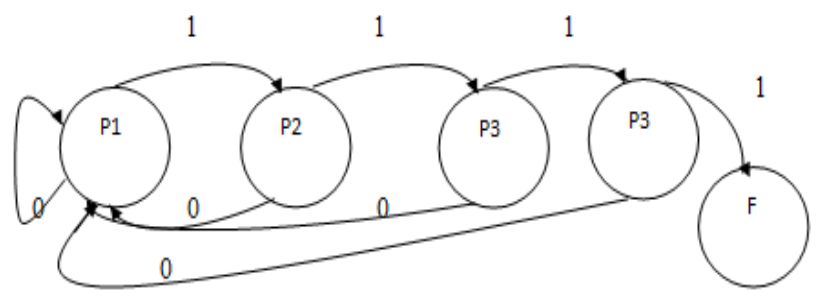

Gambar 6.Diagram FSM Level Sulit

Tabel 5.

Transisi FSM Level Sulit

\begin{tabular}{|c|c|c|}
\hline State & 0 & 1 \\
\hline P1 & P1 & P2 \\
\hline P2 & P1 & P3 \\
\hline P3 & P1 & P4 \\
\hline P4 & P1 & F \\
\hline F & $\varnothing$ & $\varnothing$ \\
\hline
\end{tabular}

P1 merupakan pertanyaan 1: Jika pertanyaan 1 dijawab dengan benar, maka next state ke pertanyaan 2. Jika pertanyaan 1 di jawab salah maka akan kembali ke pertanyaan 1. P2 merupakan pertanyaan 2: Jika pertanyaan 2 dijawab dengan benar, maka next state ke pertanyaan 3. Jika pertanyaan 2 di jawab salah maka akan kembali ke pertanyaan 1. P3 merupakan pertanyaan 3: Jika pertanyaan 3 
dija wab dengan benar, maka next state ke pertanyaan 4. Jika pertanyaan 3 di jawab salah maka akan kembali ke pertanyaan 1. P4 merupakan pertanyaan 4: Jika pertanyaan 4 dijawab dengan salah, maka akan kembali ke pertanyaan 1 dan dengan dijawab benar, maka akan berada di state akhir (F) atau permainan selesai.

\section{Tampilan Antarmuka Game}

Pertama pengguna menjalankan game dan tampilan yang akan keluar utama sebuah splash screen.

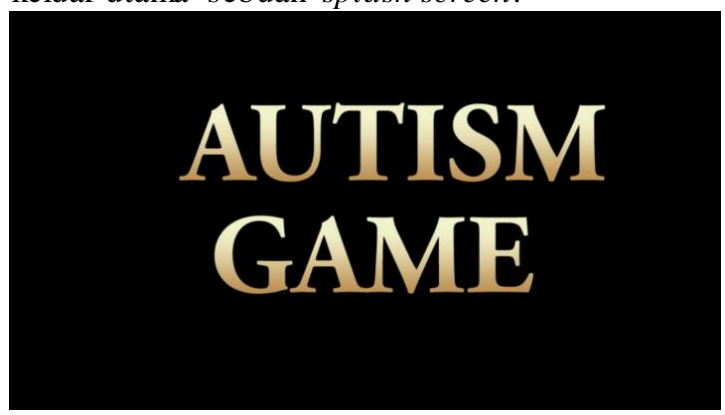

Gambar 7.Tampilan Splash Screen

Di dalam tampilan menu utama terdiri dari button mulai dan button keluar. Pengguna dapat memilih dengan menggerakkan tangan pada button mulai untuk masuk ke menu pilih level. Button belajar untuk mengenal benda yang ada dalam rumah. Button tentang untuk mengetahui pe mbuat game. Button keluar untuk menutup game.
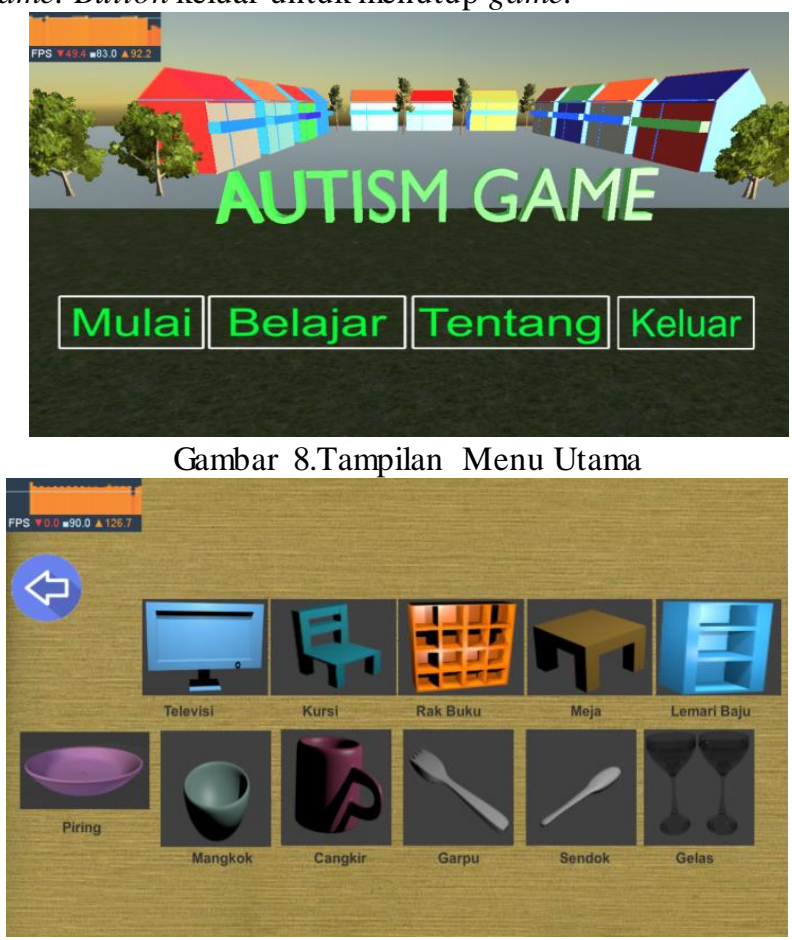

Gambar 9.Tampilan Menu Belajar

Dalam tampilan pilih level terdiri dari level mudah, sedang dan sulit. Untuk kembali ke menu utama pengguna memilih tombol panah yang terletak di pojok kiri atas.

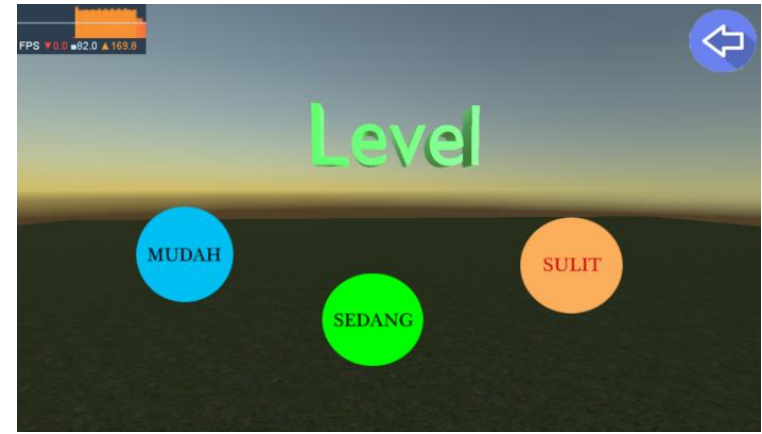

Gambar 10.Tampilan Menu Pilih level

Dalam tampilan game memilih objek pengguna harus memilih objek yang benar dari soal yang ditanyakan. Untuk kembali ke tampilan sebelumnya dapat memilih tombol kembali. Dalam game ini terdapat Timer, digunakan untuk membatasi pengguna dalam menja wab soal. Jika soal belum terjawab maka pengguna akan kembali ke tampilan pilih level. Timer yang diberikan pengguna sekitar 35 detik

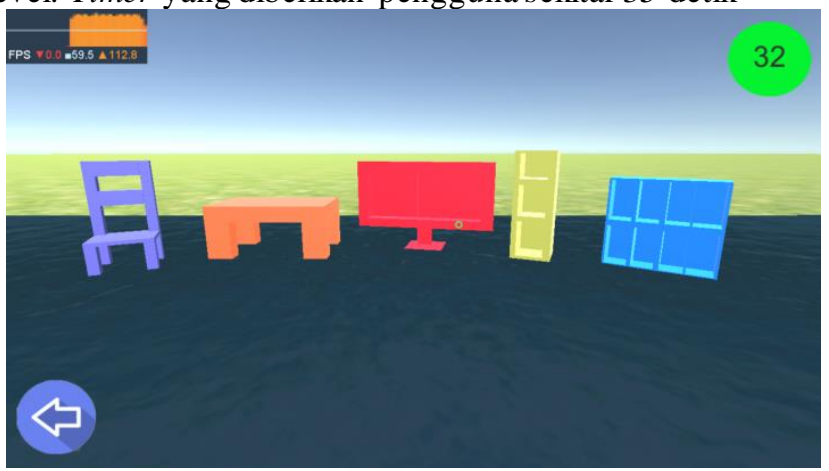

Gambar 12.Tampilan Game Memilih Obyek

Dalam game melengkapi kata pengguna harus men-drag tiga huruf yang ada di samping objek untuk melengkapi kata yang ada di bawah. Jika pemain salah meletakkan huruf maka huruf akan kembali ke ke tempat semula, jika benar huruf yang kosong akan terisi setelah di drag. Jika semua huruf sudah lengkap maka akan lanjut ke scene selanjutnya. Timer yang diberikan pengguna sekitar 45 detik

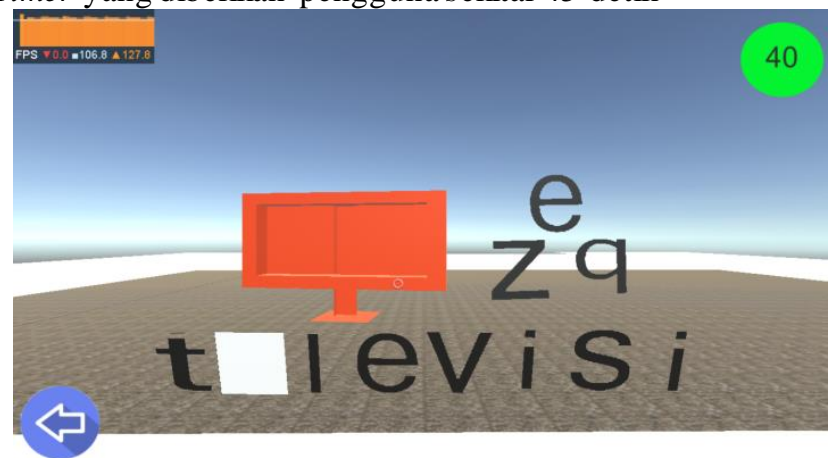

Gambar 13.Tampilan Game Melengkapi Kata

Dalam game berhitung pengguna bisa langsung menghitung banyak objek yang tampak pada layar. Jika angka yang dipilih benar pengguna akan lanjut ke scene berikutnya. Timer yang diberikan pengguna sekitar 60 detik untuk menyelesikan game berhitung. 


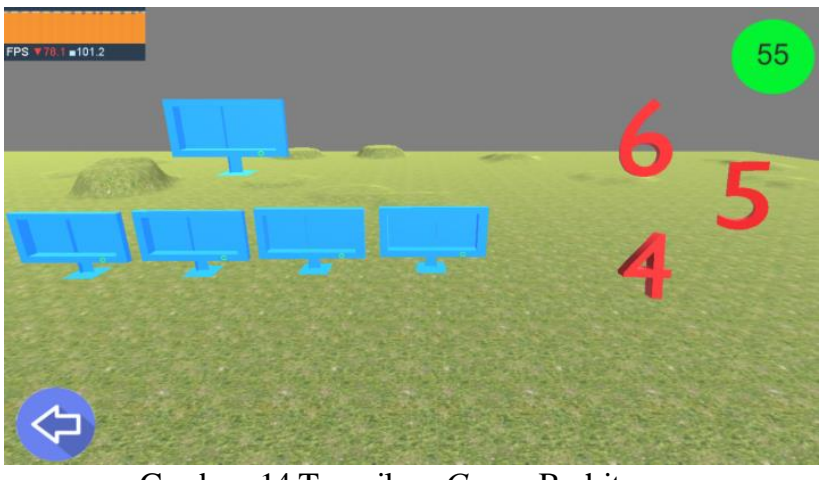

Gambar 14.Tampilan Game Berhitung

\section{E. Pengujian}

Dalam pengujian game dilakukan dengan cara menentukan rata-rata jarak kinect dengan pengguna, waktu respon tombol button dan pengujian rata-rata FPS (Frame Per Second) dalam game.

Tabel 6

Spesifikasi laptop dan notebook

\begin{tabular}{|c|c|c|c|c|}
\hline $\begin{array}{c}\text { Perangk } \\
\text { at }\end{array}$ & $\begin{array}{c}\text { Process } \\
\text { or }\end{array}$ & $\begin{array}{c}\text { Memor } \\
\text { i }\end{array}$ & VGA & $\begin{array}{c}\text { Kecepata } \\
\text { n } \\
\text { Processo } \\
\text { r }\end{array}$ \\
\hline $\begin{array}{c}\text { Asus } \\
\text { X200C } \\
\text { A }\end{array}$ & $\begin{array}{l}\text { Intel(R) } \\
\text { Celeron } \\
\text { (R) }\end{array}$ & 4GB & $\begin{array}{c}\text { Intel (R) } \\
\text { HD } \\
\text { Graphics }\end{array}$ & 1,5 Ghz \\
\hline $\begin{array}{c}\text { Dell } \\
\text { Inspiron } \\
\text { N4110 }\end{array}$ & $\begin{array}{c}\text { Intel } \\
\text { Core i5- } \\
2430 \mathrm{M}\end{array}$ & 4GB & $\begin{array}{l}\text { Intel HD } \\
\text { Graphics }\end{array}$ & 2,0 Ghz \\
\hline $\begin{array}{c}\text { Asus } \\
\text { X550Z }\end{array}$ & $\begin{array}{c}\text { AMD } \\
\text { Radeon } \\
\text { R7 }\end{array}$ & 4GB & $\begin{array}{c}\text { AMD } \\
\text { Radeon( } \\
\text { TM) R7 } \\
\text { Graphics }\end{array}$ & 2,7 Ghz \\
\hline
\end{tabular}

Pengujian game dilakukan dengan menentukan jarak dan waktu respon. Untuk pengujian jarak dilakukan dari jarak yang minimal sampai jarak maksimal game dapat dideteksi oleh kinect. Sedangkan untuk pengujian waktu respon dengan menguji tombol button yang terdapat pada game. Pengujian dilakukan sebanyak 10 kali dan menghitung ratarata dengan menjumlahkan hasil percobaan kemudian membagi dengan jumlah percobaan.

Tabel 7

Pengujian Game

\begin{tabular}{|c|c|c|}
\hline \multirow{2}{*}{ Perangkat } & \multicolumn{2}{|c|}{ Spesifikasi Pengujian } \\
\cline { 2 - 3 } & Jarak & Waktu Respon \\
\hline Asus X200CA & 2,2 meter & 1,6 detik \\
\hline $\begin{array}{c}\text { Dell Inspiron } \\
\text { N4110 }\end{array}$ & 2,2 meter & 1,3 detik \\
\hline Asus X550Z & 2,2 meter & 1,2 detik \\
\hline
\end{tabular}

Pengujian FPS dilakukan sebanyak 10 kali percobaan. Menghitung rata-rata FPS dalam game dengan cara menggunakan jarak ideal antara kinect dengan pengguna sebesar 2,2 meter. Menghitung rata-rata FPS Terbaik dan FPS terburuk dari setiap perangkat.

Tabel 8

Pengujian FPS

\begin{tabular}{|c|c|c|}
\hline Perangkat & $\begin{array}{c}\text { Rata-Rata } \\
\text { FPS Terbaik }\end{array}$ & $\begin{array}{c}\text { Rata-Rata FPS } \\
\text { Terburuk }\end{array}$ \\
\hline Asus X200CA & $105,8 \mathrm{fps}$ & $74,7 \mathrm{fps}$ \\
\hline $\begin{array}{c}\text { Dell Inspiron } \\
\text { N4110 }\end{array}$ & $113,5 \mathrm{fps}$ & $85,5 \mathrm{fps}$ \\
\hline
\end{tabular}

JOINTECS Vol. 3, No.1, Januari 2018

DOI: 10.31328/jointecs.v3i1.501

\begin{tabular}{|c|c|c|}
\hline Asus X550Z & $120,3 \mathrm{fps}$ & $87,5 \mathrm{fps}$ \\
\hline Rata-Rata & $113,2 \mathrm{fps}$ & $82,5 \mathrm{fps}$ \\
\hline
\end{tabular}

\section{KESIMPULAN DAN SARAN}

Perancangan game menggunakan software Unity 3D,Blender,Adobe Photoshop,Adobe Audition, Developer Toolkit Browser v1.8.0 dan Kinect studio v1.8. Kinect XBOX 360 digunakan untuk menangkap sensor gerakan tangan kanan yang digunakan untuk kursor dalam menjalankan game. Game ini dapat berjalan maksimal dengan spesifikasi minimal RAM 4GB dan kecepatan processor lebih dari $2 \mathrm{Ghz}$. Fitur yang terdapat dalam game diantaranya memilih objek, melengkapi kata dan berhitung. Dalam pengujian FPS dilakukan dalam jarak ideal antara kinect dengan pengguna sebesar 2,2 meter dan hasil rata-rata FPS terbaik dan terburuk yang didapat sebesar 113,2 fps dan 82,5 fps.

\section{DAFTAR PUSTAKA}

[1] Abdullah,D.,Reza,B.,Ita,Erliana,C.,"Game Edukasi Berbasis Role Playing Game Dengan Metode Finite State Machine".

[2] Haryanto.H., Novianto,S., Rosyidah,U., "Model Skenario Adaptif Berbasis Finite State Machine Pada Game Pendidikan".Techno.com,1411-3201, Vol 13, No 2, 91-98, Mei 2014

[3] Rostianingsih, S.,Satia,Budhi G., Kristian Wijaya, H., "Game Simulasi Finite State Machine Untuk Pertanian dan Peternakan".

[4] Wibowo,djoko.,Noers as oongko,edi.,Wahana,Ro mi,S.,"I dentifikasi Kesalahan dalam Mengerjakan Soal Penjumlahan Susun Berbasis Finite State Machine".Teknologi Informasi,ISSN 1414-9999, Vol 8, No 1, 1-11, April 2012

[5] Haryanto,H.,Hariadi,M., "Sistem Reward Imersif berbasis Finite State Machine Pada Game Pembelajaran Bahasa Inggris Untuk Siswa Sekolah Dasar".Seminar Sistem Informasi Indonesia,Desember 2008.

[6] Fauzan,M.R., Suyatno,A., Maharani,S., "Penerapan Metode Finite State Machine Pada Game"The Relationship" ".Jurnal Informatika Mulawarman,14113201,Vol 11, No 1, 14-22, Februari 2016

[7] Haryanto,H.,"Agen Cerdas Kompetitif Berbasis Finite State Machine Dalam Game Pembelajaran Untuk Anak".Techno.com, Vol 9,No 2,Mei 2010

[8] Jannah,Aisyah,Rahmatul.,"Game Edukasi Bahasa Arab Untuk Anak Berbas is Dekstop".2-7.

[9] Faizal,Ade.,Astuti,Setia.,"Game Edukasi Pengenalan Transaksi Belanja dan Pengenalan Nilai Mata Uang Untuk SDLB-C Widya Bhakti Semarang Dengan Metode FSM".1-12

[10] Haryanto,H.,"Reward Dinamis dalam Skenario Adaptif Menggunakan Metode Finite State Machine pada Game Edukasi'.Journal of Applied Intelegent System, Vol 1,No 2,144-153,Juni 2016

[11] Bimantoro,T.,Haryanto,H.,"Pemodelan Perilaku Musuh Menggunakan Finite State Machine (FSM) Pada Game Pengenalan Unsur Kimia"Journal of Applied Intelegent System, Vol 1, No 3, 210-219,Oktober 2016

[12] Cancela,J.,Hurtado,O.,Arredondo,Maria,T.,"Proposal of a KinectTM-based System for Gait Assesment and Rehabilition in Parkinson's Disease".IEEE.4519-4522. 
[13] Morgan,B.,Kehtkar,F.,Graesser,A.,Shaffer,D.,"Automat ing the Mentor in a Serious Game:A Discourse Analysis Using Finite State Machines".591-595. 